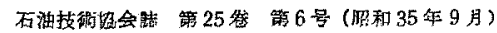

JOURNAL OF THE JAPANESE ASSOCIATION OF PETROLEUM TECHNOLOGISTS

VOL. 25. NO. 6 (Sept., 1960)

\title{
坑井の自噴促進への泡洙現象の応用
}

第1 報 水を伴ならガス井に閣する基礎的実験

狄 野 典夫* 村上 政 美*

(昭稩 35 年 5 月 30 日受㹤)

\section{Application of Foams to Remove Water Column in Wellbores}

Part-1 Fundamental Experiments of Model Gas-Well

By

Norio OGino \& Masami Murakami

\begin{abstract}
The accumulation of water in wellbores has become difficult to produce natural gas and liquid hydrocarbons. In that place, the application of foams to remove water column and foaming ability of non-ionic surface active agents is described in this paper.
\end{abstract}

\section{1. 緒言}

水军伴なつてくるガス井に扎いて，てのウォターカラ ムが序々に罢積し，障害上なつてし生，その応急処置 として，従来ベイラーを使用したりスワビンダを行つて 排除することによつて，ガスの産出量の隇退や自獖停止 状態をまたもと通りに復元させてきた。しかしながら， ぶイラーを使つたりスワビング作業を行ら費用はなかな か高価であり，所要時間も大きい。

そこで，泡沫現象の呈する性状に着目して，かような 水を多量に伴なってくるガス井に対して，起泡性に豊双 安定性も適度なフォーミンダェイジンント添加するこ とによつて，障害となつて拈るウォタ一カラム在回収し 去る奏験空的な基礎実験を行つた次第である。このフォ 一ミングエイジェントを添加する方法では，操作・使用 法が簢便であるばかりでなく，経費水も低廉ですむこと が特色さされている。しかしながら，ガスに伴なわれて 産出してくる水量がきわ力て微䑁である坑井や，最早採 算上の収支が取れないまでに減退し切つてしまつた坑井 に対しては，起泡力に拁いて充分な機能を発揮しないの で，適用することはできない。

* 砇国石油 K.K. . 中央研等所

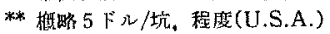

\section{2. 泡沫現象*の概要}

気体・淮体また固体中に浮游したものが気泡であ. りこのものが浮上して数多く集合し，お互いに薄膜で 距てられた状態を呈して㧍るものが泡沫というものであ る。そして泡洙現象，すなわ泡立ちとは

（a）起泡力（泡立ち易さ） Foaming ability

(b) 安定度 (泡の寿命) Foaming stability の2因子によって，はビめて定義ゔけられるものであ る。静的泡沫の場合に㧍ける泡沫の平均寿命 $\tau$ は，送気 法で泡沫索作りこれを放置する際の残存泡膜液量, また は泡沫気体量它 Vとすると,

$$
\begin{aligned}
& V=V_{0} f(t) \quad V_{0}: \text { 時間 } t=0 \text { に扝ける泡洙液量 } \\
& \tau=\int_{0}^{\infty} t f^{\prime}(t) d t=\frac{1}{V_{0}} \int_{V_{0}}^{0} t d V
\end{aligned}
$$

一般に, $\quad f(t)=e^{-k t}$

したがつて、 $\tau=\frac{1}{V_{a}} \int_{0}^{\infty} \mathrm{V} \mathrm{dt}=-\frac{1}{\mathrm{k}}$

そして，泡沫崩壊の初期における $\mathrm{k}$ 性幾分大きく，末期 に近つくく従つて小さくなる。

動的泡沫の場合に打ける起泡力についても，送㼡によ つて泡立ちつ〉ある泡洙の高さを $\mathrm{H}$ ，泡洙容積を $\mathrm{V}$, 送

* ref., Sasaki : Bull. Chem. Soc. Japan 13, 669(1938) 
気の線速度和よび容積速度をそれぞれ $\mu, \mathrm{v}$ とすると

$$
\mathrm{S} \equiv \frac{\mathrm{H}}{\mu}=\frac{\mathrm{V}}{\mathrm{v}}
$$

実際には， $\mathrm{S}=\frac{\mathrm{H}-\mathrm{a}}{\mu} \quad \mathrm{a} ：$ 常数

すなるち，泡沫の高さH加ら一定值 aを引いた值の 方がのは定となる場合が多く，不安定泡沫の寿命を表 わすのに都合がよい。

無機電解筫水溶液は一般に不安定な泡沫を生成するる。 そして電解翼は普通, 員吸着在行うから, 強固な吸着膜 は作らないが，濃い苛性曹澾溶液の上うに粘性の大きい ものや，塩化アルミニけ㠷うに加水分解によつて不 溶性の物筫を生ずる傾句のあるのは，や>强い泡立ち を示寸ことになる。無機物翼に較心て有機物質の水溶液 は一般的にいつて泡立ちの上いものが多い。そして低分 子物質と高分子物質に分類して若えて見ると，低分子物 質としてはアルコール䫐・脂肪酸類はある最適濃度にお いて上く泡立ち，合成界面活性剂や色素山起泡力の極大 部が平坦であり，謴度が高くなる程，安定な泡沫を生成 する。

典型的な泡沫生成物淛の分子構造注 $\mathrm{OH}, \mathrm{CO}, \mathrm{COOH}$, $\mathrm{COO}^{-}, \mathrm{CONH}_{2}, \mathrm{CO}=, \mathrm{NH}_{2}, \mathrm{C}-\mathrm{C}, \mathrm{OSO}_{3}, \mathrm{SO}_{3} \cdots$ の親 水基上 $\mathrm{C}_{\mathrm{n}} \mathrm{H}_{2 \mathrm{n}+1}, \mathrm{CH}_{2} \mathrm{CH}: \mathrm{CH}_{2}, \mathrm{C}_{\mathrm{n}} \mathrm{H}_{2 \mathrm{n}}+{ }_{1}-\mathrm{CH}_{2} \mathrm{CH}$ :

$\mathrm{CH}_{2} \cdots$. 柾水基上より成立つて扝り，その極性と無極 性とがバランスした所で起泡力が最大上なる。例えば R-Xなる分子構造に扮いて,

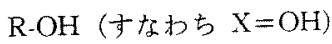

$$
\begin{aligned}
& \text { ならば } \mathrm{R}=\mathrm{C}_{4} \mathrm{H}_{9} \sim \mathrm{C}_{5} \mathrm{H}_{11} \\
& \mathrm{R}-\mathrm{COOH} \text { (すな施ち } \mathrm{X}=\mathrm{COOH} \text { ) } \\
& \text { ならば } \mathrm{R}=\mathrm{C}_{6} \mathrm{H}_{13} \sim \mathrm{C}_{7} \mathrm{H}_{\mathrm{i}} \mathrm{s} \\
& \text { R-COO- (すなわち } \mathrm{X}=\mathrm{COO}^{-} \text {) } \\
& \text { ならば } \mathrm{R}=\mathrm{C}_{12} \mathrm{H}_{25} \sim \mathrm{C}_{11} \mathrm{H}_{29} \\
& \text { R-SO- (すなわち } \mathrm{X}=\mathrm{SO}_{4}^{-} \text {) } \\
& \text { ならば } \mathrm{R}=\mathrm{C}_{12} \mathrm{H}_{25} \sim \mathrm{C}_{14} \mathrm{H}_{29}
\end{aligned}
$$

の炭秦数を持つたものが起泡力が優れておる。

温度の上昇に伴なら極性の増大については,

$$
\begin{gathered}
\mathrm{C}_{12} \mathrm{H}_{25}-\mathrm{SO}_{4} \mathrm{Na} \text { 唖極基とのバランスを破つて起 } \\
\text { 泡性が減少する。 } \\
\mathrm{C}_{16} \mathrm{H}_{33}-\mathrm{SO} \mathrm{Na} \text { は無極基とのバランスに近ふくた } \\
\text { かに起泡性が増加する。 } \\
\mathrm{R}=\mathrm{C}_{4} \mathrm{H}_{9} \sim \mathrm{C}_{7} \mathrm{H}_{15} \text { の吸着層では分子の横の結合 } \\
\text { 力*が弱く泡涑は不安定。 } \\
\mathrm{R}=\mathrm{C}_{12} \mathrm{H}_{25} \sim \mathrm{C}_{14} \mathrm{H}_{29} \text { に扔いては充分な安定性を示 } \\
\text { し起泡性に豊む。 }
\end{gathered}
$$

結局，溶質が泡立ちの良好な溶液を作るためには有

\footnotetext{
* Lateral force
}

極一無極のバランスが適度で，強い吸着性を走すととも に，踈水基が十分に細長くて上く垂直に配向しており， 横の結合力の大きな強固な膜老形成することが必要で ある。例えバランスは良くても，踈水基の炭素数が少な かつたり，分枝をもつていたり，炭素䥊の中央に親水基 が存在して吸着膜が緩かな分子莓造をもつておるもの は，泥立ちにくくなる。它た有極一無極のバランスに拉 いてRが $\mathrm{C}_{10} \mathrm{H}_{21}, \mathrm{C}_{12} \mathrm{H}_{25}, \mathrm{C}_{14} \mathrm{H}_{29}, \mathrm{C}_{16} \mathrm{H}_{33} \cdots$ の脂肪酸 ナトリウムについて起泡性の最適 $\mathrm{pH}$ を調心て見ると， 低級脂肪酸ナトリウムほど $\mathrm{pH}$ の低、所で高い起泡性を 示す。このことは低級のものほど, 柾水基に対して親水 基の強度が大き過ぎるので，pH 庄下げることによって $\mathrm{COO}^{-} \rightarrow \mathrm{COOH}$ 入上親水性を弱めることによつて適度の バランスが得られる結果，上く泡立つようになる。理論 的にも温度を上昇すると親水性が增大寸る結果，この最 大泡沫の $\mathrm{pH}$ が下ることと一致する。

一般に有機溶媒中に扔ける泡沫は水溶液の場合に比し て遙かに不安定で，甘いぜい数10秒程度である。そし て，有機溶媒中に㧍ける泡沫の特徴は溶媒による影響が 大きいことで, 溶買の化学構造以外に溶媒の特性が大き な影響老及ぼす。例えば，アルコールの上うに透電恒数 の大きな溶媒中では，小さな溶媒中上りむ起泡性に豊む 性状莡呈する。

\section{3. 実験装置および実験方法}

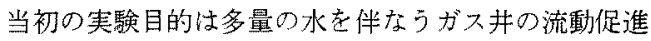
効果が，唯一の対象と考えられて来たが，寒験の進展に つれて, 適用可能坑并孔泡沫現象の応用範用も次第に变 貌して行つた。すなわち

(a) 水を伴なら以外に油相が游していたり，エマル

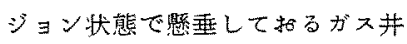

(b) $10 \%$ 以上の水を伴な5，ある種の油井 このような坑井に対してはもちろん，起泡力が極度に低 下してしまうので，特殊な乳化機能をもつたフォーミン グエイジェントを適用しなけれ代ならない。

第 1 図に示した如く所定濃度の試料 $500 \mathrm{cc}$ を，側方 の流入口より直径 $4 \mathrm{~cm}$ ，長さ $180 \mathrm{~cm}$ のガラス製力ラム 内人導入させ，下方上り空気索一定流速*で厚さ $1.5 \mathrm{~cm}$ のサンドストンディスタを流通させる。かようにして， 累積したウォターカラムが障害となつて扔るガス井を模 擬した基礎実験の資料しして，次の諸奏験值を测定す 万。
A …座出するガスの流速（cc/min.）
$\mathrm{B} \cdots$ 少スの産出庄力 $(\mathrm{cm}-\mathrm{Hg})$
C…坑外にリフトされた液量 (cc)
$\mathrm{D} \cdots$ …ウォターカラムの液面 $(\mathrm{cm})$ 


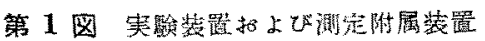

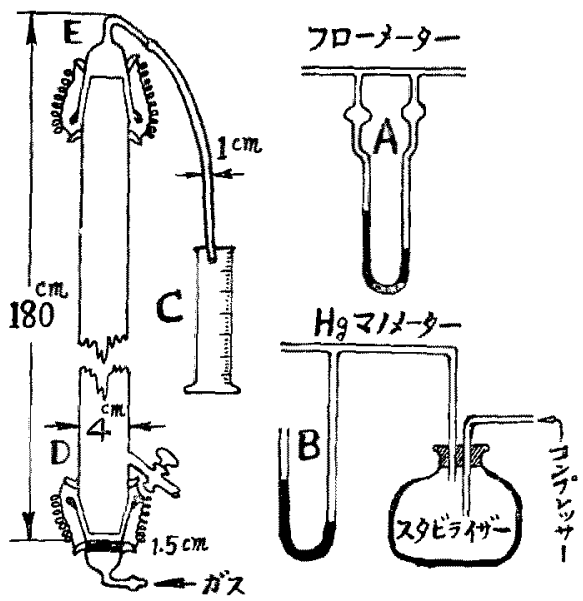

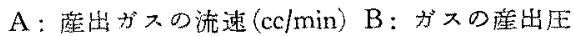

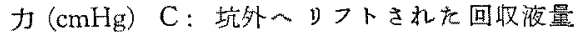

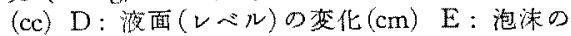
坑口一の到達時閒 (min)

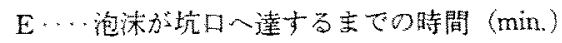

\section{4. 基碟実験結果}

(a) 害駼試料 次表に示すま5な種々の非イカン系 界面活性绪について起泡力上障害となつて抢万名多一

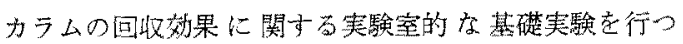
to
性状の概賗は次の如きるのである。

\begin{tabular}{|c|c|c|c|}
\hline No. 5 , & 陚料：E & 温度 $20^{\circ} \mathrm{C}$ & 温度 $60^{\circ} \mathrm{C}$ \\
\hline 㳖 面 & 涱 力 & 31.7 dyne $/ \mathrm{cm}$ & 32.4 dyne $/ \mathrm{cm}$ \\
\hline 界 面 & 馒力 & 20.0 & 24.5 \\
\hline
\end{tabular}

最点む $4 \%$ 水溶液に扔いて $35 \sim 44^{\circ} \mathrm{C}$ て酸に対しては conc. $\mathrm{H}_{2} \mathrm{SO}_{4}$ 以外姑定であり，アルカリに対しても5 $\%$ 以の $\mathrm{NaOH}$ 以外梳定性示李。

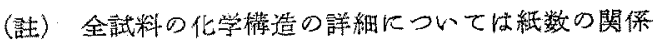
で省略する。な极，非イオン系界面活性削の一般通

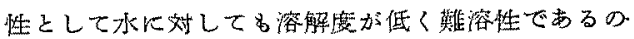

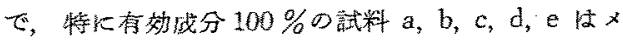

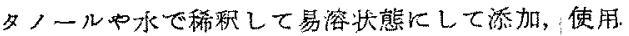
するとと。

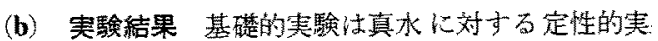
験を経て，坑井水と同じ塩水につれての笑験を終えて，

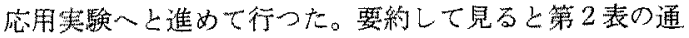
りである。

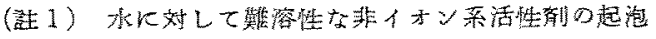

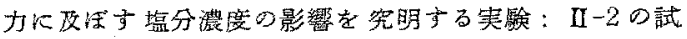

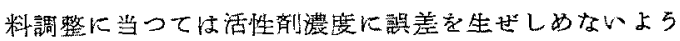

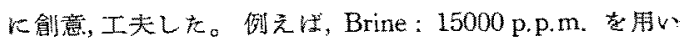

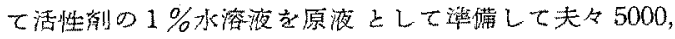
$10000 ， 15000 ， 20000$ p.p.m. の試数を調製した。

5000 p.p.m. ……原液 $100 \mathrm{cc} \kappa 15000$ p.p.m. ,

第 1 表

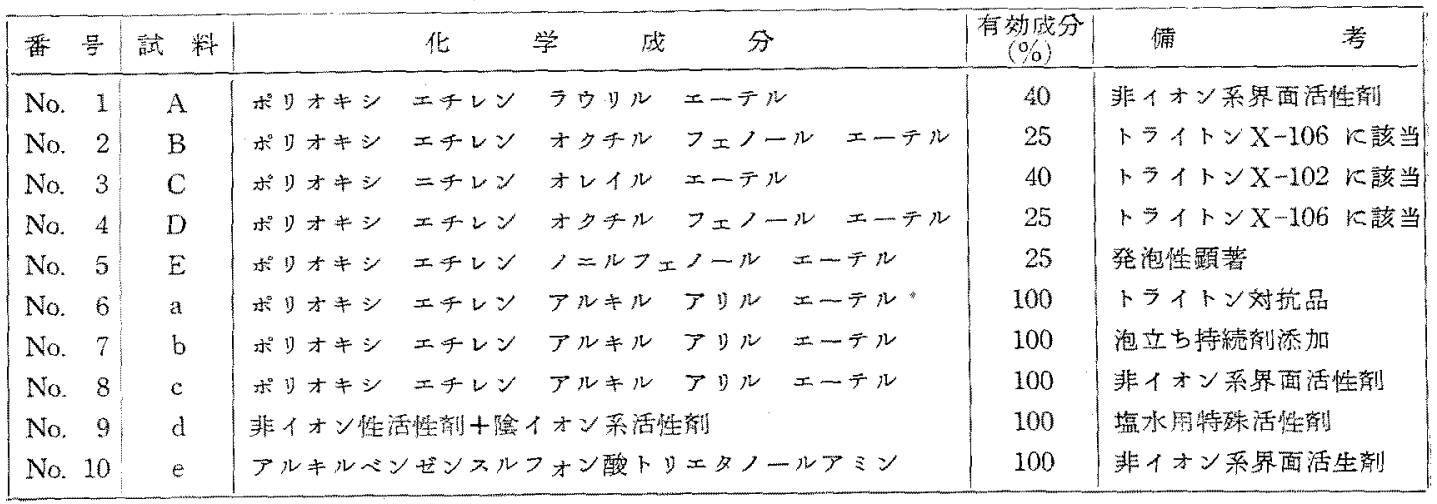

No. 5 の試科海第1表でホしたようにポリオキシエチ

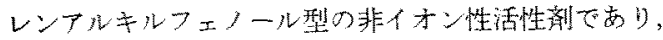
一般式として汶次のようなのである。<smiles>[R]c1cccc(OCCOO)c1</smiles>

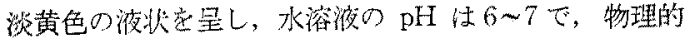

Brine $233 \mathrm{cc}$ ，真承 $667 \mathrm{cc}$ 加党て 5000 p.p.m. の試料 $1 l$ 㐘䄍る。

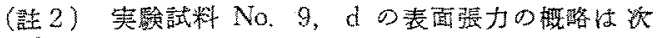
の如 ᄂ。

\begin{tabular}{|c|c|c|c|}
\hline 程分灃度 & 港加袁: & at $15^{\circ} \mathrm{C}$ & at $40^{\circ} \mathrm{C}$ \\
\hline $\begin{array}{l}\text { p.p.m. } \\
15000\end{array}$ & $\begin{array}{r}\% \\
0.50\end{array}$ & $\begin{array}{l}\text { dyne/cm } \\
34.52\end{array}$ & $\begin{array}{l}\text { dyne } \mathrm{cm} \\
31.65\end{array}$ \\
\hline 15000 & 0.25 & 34.68 & 33.55 \\
\hline
\end{tabular}




$\begin{array}{rlll}15000 & 0.10 & 34.95 & 34.03 \\ 20000 & 0.10 & 33.82 & 33.01 \\ 15000 & 0.10 & 34.95 & 34.03 \\ 10000 & 0.10 & 34.60 & 33.63 \\ 5000 & 0.10 & 34.35 & 33.32 \\ 20000 & 0.05 & 35.67 & 34.81 \\ 10000 & 0.05 & 35.79 & 35.26 \\ 5000 & 0.05 & 36.74 & 36.00\end{array}$

（註 3）應出が Х量が少ない間は油相部分とウォター カフム閶には明瞭に2 圈をなしケロジンの上部でか すかに泡涑を形成する程度であるが，炊第にガス靠 が増すに連れて2 層の界面で焉化し始めに $300 \mathrm{cc}$ min Кなるをカラム全体加乳化するに至る。

上表に特りる表面張力の同部的な買常变化はド デシルサルフェートにも見られる現象である。

\begin{tabular}{|c|c|c|c|c|c|c|c|}
\hline 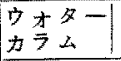 & 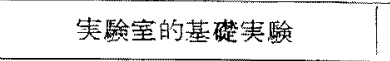 & 試料 & 添 & 加 & 墨 & 備 & 考 \\
\hline \multirow{3}{*}{ 真 水 } & 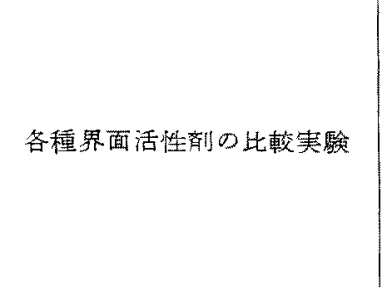 & $\begin{array}{lll}\text { No. } & 1, & \text { A } \\
\text { No. } & 2, & \text { B } \\
\text { No. } & 3, & \text { C } \\
\text { No. } & 4, & \mathrm{D} \\
\text { No. } & 5, & \mathrm{E} \\
\text { No. } & 6, & \text { a } \\
\text { No. } & 7, & \mathrm{~b} \\
\text { No. } & 8, & \mathrm{c} \\
\text { No. } & 9, & \mathrm{~d} \\
\text { No. } & 10, & \mathrm{e}\end{array}$ & $\begin{array}{l}\% \\
0.1 \\
0.1 \\
0.1 \\
0.1 \\
0.1 \\
0.1 \\
0.1 \\
0.1 \\
0.1\end{array}$ & $\begin{array}{l}0.5 \% \\
0.5 \\
0.5 \\
0.5 \\
0.5 \\
0.5 \\
0.5 \\
0.5 \\
0.5\end{array}$ & $\begin{array}{l}1.0 \% \\
1.0 \\
1.0 \\
1.0 \\
1.0 \\
1.0 \\
1.0 \\
1.0 \\
1.0\end{array}$ & 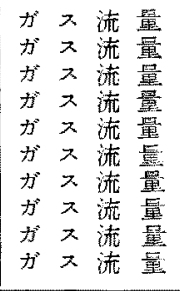 & $\begin{array}{l}300 \mathrm{cc} / \mathrm{min} \text {. } \\
300 \mathrm{cc} / \mathrm{min} \\
300 \mathrm{cc} / \mathrm{min} . \\
300 \mathrm{cc} / \mathrm{min} \\
300 \mathrm{cc} / \mathrm{min} \text {. } \\
300 \mathrm{cc} / \mathrm{min} . \\
300 \mathrm{cc} / \mathrm{min} \text {. } \\
300 \mathrm{cc} / \mathrm{min} . \\
300 \mathrm{cc} / \mathrm{min} \text {. } \\
300 \mathrm{cc} / \mathrm{min}\end{array}$ \\
\hline & 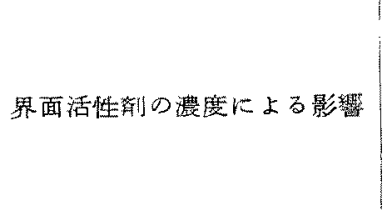 & $\begin{array}{ccc}\text { No. } & 2, & \text { B } \\
\text { No. } & 2, & \text { B } \\
\text { No. } & 2, & \text { B } \\
\text { No. } & 2, & \text { B } \\
\text { No. } & 2, & \text { B } \\
\text { No. } & 2, & \text { B } \\
\text { No. } & 2, & \text { B }\end{array}$ & & $\begin{array}{l}0.01 \\
0.03 \\
0.05 \\
0.10 \\
0.30 \\
0.50 \\
1.00\end{array}$ & & 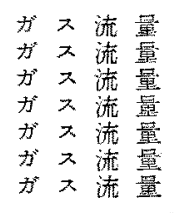 & $\begin{array}{l}300 \mathrm{cc} / \mathrm{min} . \\
300 \mathrm{cc} / \mathrm{min} . \\
300 \mathrm{cc} / \mathrm{min} . \\
300 \mathrm{cc} / \mathrm{min} . \\
300 \mathrm{cc} / \mathrm{min} . \\
000 \mathrm{cc} / \mathrm{min} . \\
300 \mathrm{cc} / \mathrm{min} .\end{array}$ \\
\hline & 産出するガス流量による影響 & $\begin{array}{lll}\text { No. } & 2, & \text { B } \\
\text { No. } & 2, & \text { B } \\
\text { No. } & 2, & \text { B } \\
\text { No. } & 2, & \text { B } \\
\text { No. } & 2, & \text { B }\end{array}$ & & $\begin{array}{l}0.5 \\
0.5 \\
0.5 \\
0.5 \\
0.5\end{array}$ & & $\begin{array}{ll}\text { 流 } & \text { 速 } \\
\text { 流 } & \text { 速 } \\
\text { 流 } & \text { 速 } \\
\text { 流 } & \text { 速 } \\
\text { 流 } & \text { 速 }\end{array}$ & $\begin{array}{l}200 \mathrm{cc} / \mathrm{min} . \\
300 \\
400 \\
500 \\
1000\end{array}$ \\
\hline \multirow{4}{*}{ 塩 水 } & 塩氷に詨する比較実馱 & $\begin{array}{lll}\text { No. } & 1, & \text { A } \\
\text { No. } & 2, & \text { B } \\
\text { No. } & 3, & \text { C } \\
\text { No. } & 4, & \text { D } \\
\text { No. } & 5, & \text { E } \\
\text { No. } & 6, & \text { a } \\
\text { No. } & 8, & \text { c } \\
\text { No. } & 9, & \text { d } \\
\text { No. } & 10, & \text { e }\end{array}$ & & $\begin{array}{l}0.1 \\
0.1 \\
0.1 \\
0.1 \\
0.1 \\
0.1 \\
0.1 \\
0.1 \\
0.1\end{array}$ & & 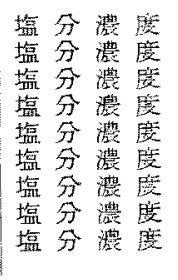 & $\begin{array}{l}15000 \text { p.p.m. } \\
15000 \text { p.p.m. } \\
15000 \text { p.p.m. } \\
15000 \text { p.p.m. } \\
15000 \text { p.p.m. } \\
15000 \text { p.p.m. } \\
15000 \text { p.p.m. } \\
15000 \text { p.p.m. } \\
15000 \text { p.p.m. }\end{array}$ \\
\hline & 塩分濃度に上る影留 & $\begin{array}{lll}\text { No. } & 9, & d \\
\text { No. } & 9, & d \\
\text { No. } & 9, & d \\
\text { No. } & 9, & d\end{array}$ & & $\begin{array}{l}0.1 \\
0.1 \\
0.1 \\
0.1\end{array}$ & & 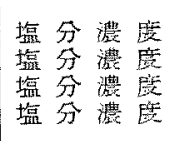 & $\begin{array}{l}5000 \text { p.p.m. } \\
10000 \text { p.p.m. } \\
15000 \text { p.p.m. } \\
20000 \text { p.p.m. }\end{array}$ \\
\hline & 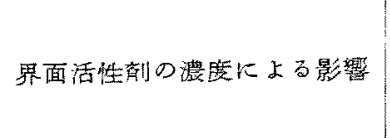 & $\begin{array}{lll}\text { No. } & 9, & \mathrm{~d} \\
\text { No. } & 9, & \mathrm{~d} \\
\text { No. } & 9, & \mathrm{~d} \\
\text { No. } & 9, & \mathrm{~d}\end{array}$ & & $\begin{array}{l}0.01 \\
0.03 \\
0.05 \\
0.10\end{array}$ & & 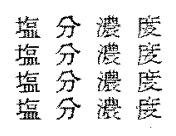 & $\begin{array}{l}15000 \text { p.p.m. } \\
15000 \text { p. p.m. } \\
15000 \text { p.p.m. } \\
15000 \text { p.p.m. }\end{array}$ \\
\hline & 油相が浮游状驡で存在する場合 & $\begin{array}{lll}\text { No. } & 9, & \mathrm{~d} \\
\text { No. } & 9, & \mathrm{~d} \\
\text { No. } & 9, & \mathrm{~d}\end{array}$ & & $\begin{array}{l}0.10 \\
0.10 \\
0.10\end{array}$ & & $\begin{array}{l}\text { ケシン } 2 \% \\
\text { ケシシン } 10 \% \\
\text { ケシシン } 20 \%\end{array}$ & 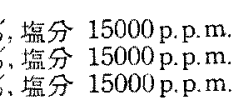 \\
\hline
\end{tabular}




\section{5. 考察および今後の問題}

実験室に扔ける起泡力に関眑する基礎的実駼を行つた 結果，大要次に述べるよらな項目が明らかとなつた。

（a）真水に対寸る基磷的な実験：I-1を行った結果， 試料B扮上びD（ポリオキシエチレンオクチルフェ ノールエーテル）が起泡性に执いて優れ，障害となっ ておるウォターカラムの回收率む良好である。また発泡 郕としての非イオン系界面活性剤の添加量も， $0.1 \%$ と $0.5 \%$ の間では起泡力の強弱が明瞭に現われているが, $0.5 \%$ よ添加量を增して見ても，起泡力とウォターカ ラム回取機能上に最早影響を及ぼすことがない(第 2 図 $\mathrm{a}$, 参照)。

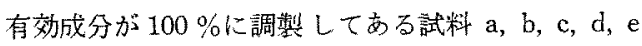
に対して注，発泡剂の添加量注 $0.1 \%$ で既に充分な起泡 力を発揮してく机る(第2図 $\mathrm{b}$, 参照)。

(b) 試料 $\mathrm{B}$ (ポりオキシエチレンオクチルフェ イール）について添加量による起泡力の受ける影響を調

第 2 図 (a)' ガス水比 $(G / W)$ の変化

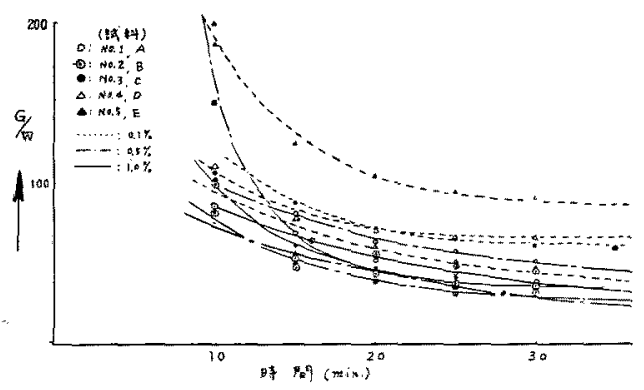

第 2 図(a) 各種非イオン系活性削の真水 K対与る起泡力比較実魜

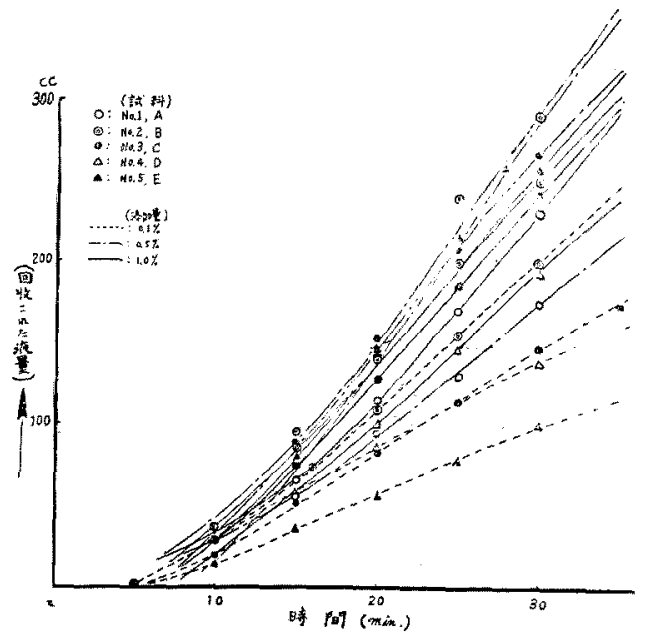

第 2 図(b) 各種活性削の真水に対する起 泡力比較実験

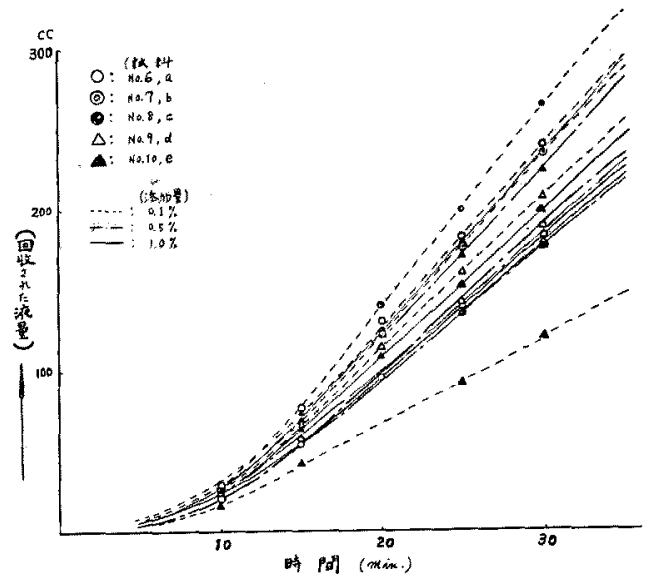

第 2 図(b) ガス水比 $(\mathrm{G} / \mathrm{W})$ の变化

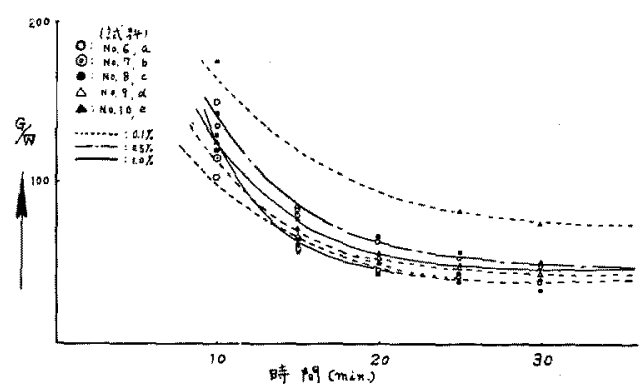

ベて見ると，添加量が $0.5 \%$ 以上になると起泡力とウォ ターカラムの回收の上に注影響を及隹さない。な斿，試 料の有効成分は $25 \%$ \%のである(第 3 四参照)。

第 3 图真水に対する添加量に上る影鄉

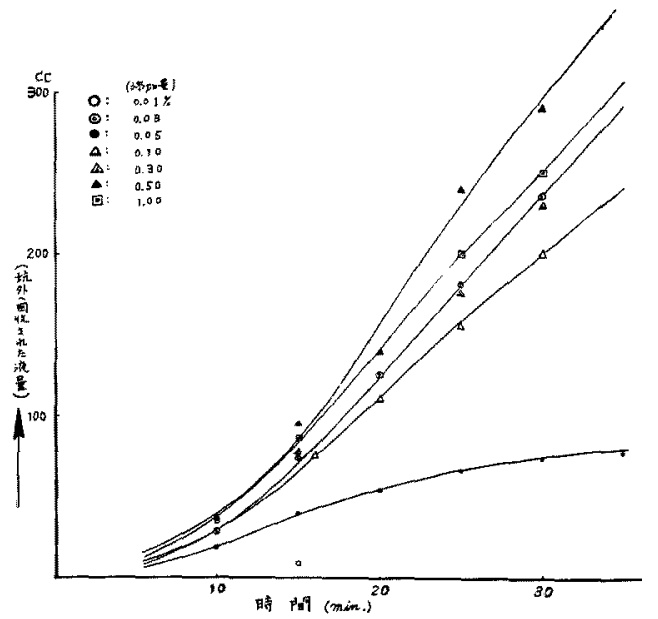


（c）童出するガスの流量は起泡力の促進機能上に著 しい影響を及ぼし，したがつてウォターカラムの回収率 はガスの流速に比例して增大して行く(第 4 図参照)。

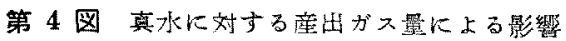

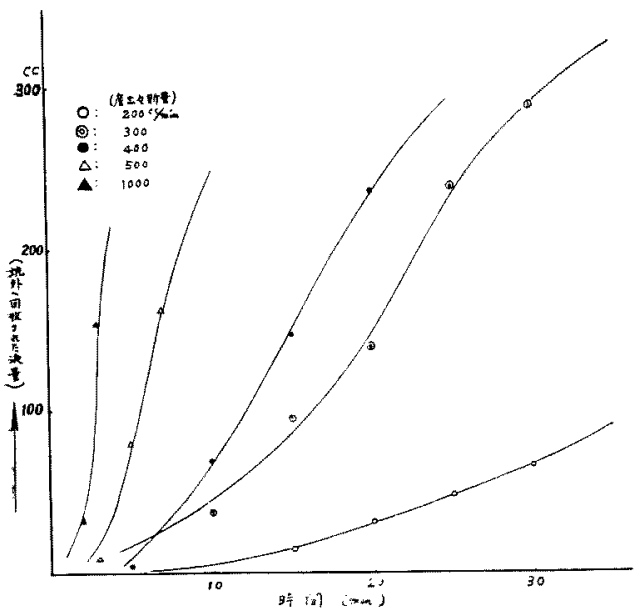

（d）塩水に対す万基礎的実験を各璉の発泡削につい て行つた所，塩水用に特別に調整した試料： $\mathrm{d}^{*}$ が起泡 性，および回权率において優れておる。ただし，試料 $\mathrm{B}, \mathrm{D}, \mathrm{E}$ の有効成分は $25 \%$, 試料 A，Cの有效成分は

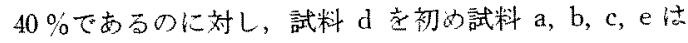
有効成分 $100 \% * *$ のものを実験用に供した（第 5 図参 照)。

第 5 図塩水に対する起泡力比較実驗

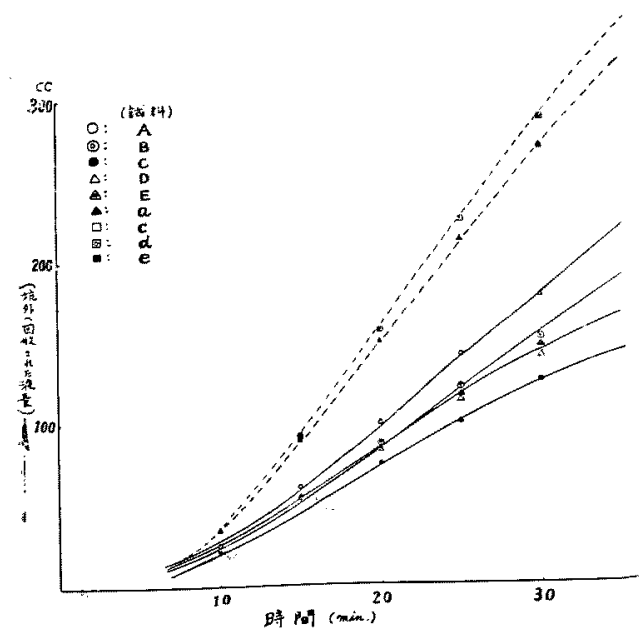

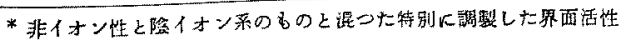

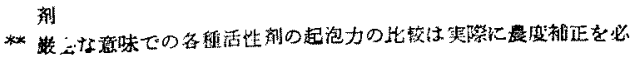
要とする (e) 塩水用に特別調製の試料：dに扎てた，塩分 濃度によつて著しい影響は受けず，塩分濃度の増加につ れて起泡性が幾分低下して行く傾向交す程度である。 したがって，塩水用の発泡剤であるならば，塩分濃度を ほとんど考慮する必要がない(第6 図参照)。

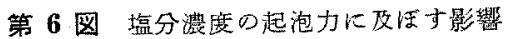

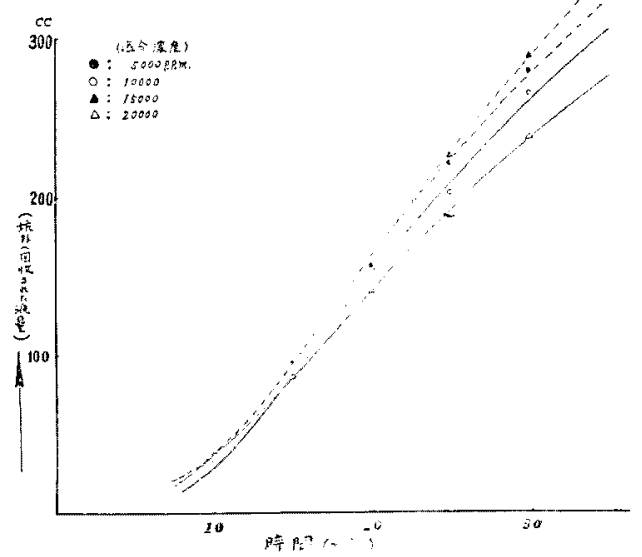

（f）塩水用の特殊試料：d の添加量による起泡力の 響影を調べた所， $0.1 \%$ 程度の添加量までは濃度が増大 するにつれて起泡力b上昇して行く(第7图参照)。

第 7 図塩水に対する活性㸝の添加量

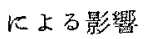

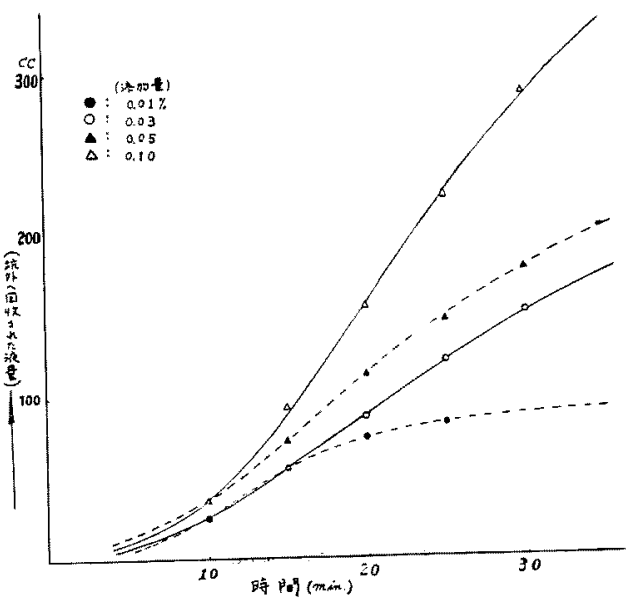

（g）油相部がウォターカラムの上部こ浮遊状態で存 在して扔る場合に，乳化機能も带びて抗る特殊調製試料: d妾用いての契験によると，油相部分がウォターカラム に対し $20 \%$ 程度*ならば起泡力おるび回収率の減退を招

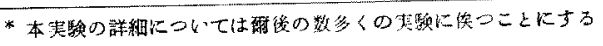


第 8 図程水に油相が浮游状懸で存在し て扣る状態のもとでの荚験

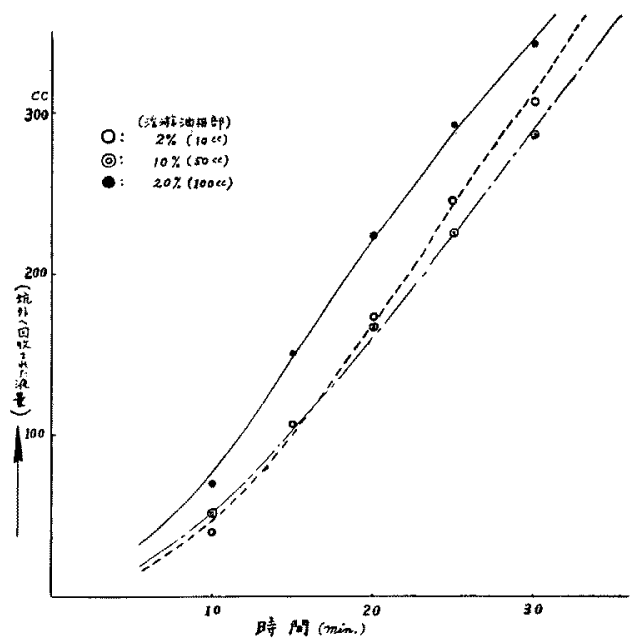

来しない(第 8 図参照)。

今後の問題：油相がウォターカラムの上部に浮游状態 で存在して扣る基整的实跧を一段之我躍させて，ある程 度の竝井水を伴な5油井に对する泡沫現象の応用は, 一 般的概念加占考えれば不可能に近く, 誰からる振向好れ ないだけになかなか興味ある問題である。しかしなが ら, 前速して通り一般有機溶媒中に批いて子起泡力は極 度に低下するもので, 普通の非イオン系界面活性削では フォーミンダェイジェントとしての用をなさない。

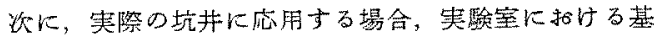

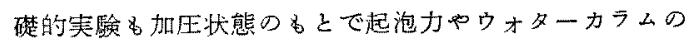
回収芙歌を行つて，このととについても究明して見なけ ればならない。な招物理的な間題となるが, 添加方法、 操作の諸点についても慎重に考究する必亚がある。
謝辞 種々御教示賜つた東大淵旺教授, 技研斎藤主任 和よび柏钩生座䵠の方々に対し表心より謝意を表する次 第である。

\section{参考文献}

1) H. N. Dunning, J. L. Eakin etc. : Foaming Agents, cure for water-logged gas wells, The Petroleum Engineer, Nov., 1959.

2) H. N. Dunning \& J. L. Eakin: Foaming Agents are Low-cost Treatment for Tired Gassers, Oil \& Gas Jour., 57, No. 6, 108 (Feb. 2, 1958).

3) B. V. Randall, J. L. Lummus \& R. P. Vincent: Combatting Intermediate Quantities of Water in Air/Gas Drilling, The Petroleum Engineer, Vol. 30, No. 12, B 26-29, Nov. 1958.

4) M. N. Fineman, G. L. Brown \& R. J. Myers: Foaming of Non-ionic Surface Active Agents, $J$. Phys. Chem.,56, 963, 1952.

5) Bikerman: Foams, Waverly Press, Inc., 164, 1953.

6) Bikerman : Foams, Waverly Press, Inc. 55-69, 1953.

7) Matalon: Surface Chemistry, Faraday Soc. and Soctétè de Chimie Physique, 195, 1949.

8) Sasaki : Bull. chem. Soc. Japan, 13, 517, 1938.

9) Sasaki : Bull. chem. Soc. Japan, 13, 669, 1938. 泡沫現象，化学实驗学，物理化学，第 4 巻 (河出 畫房).

10) Sasaki (佐々木恒孝) : Bull. Chem. Soc. Japan, $15,449,1940$.

（註）翡イオン菜界面活性削の一般的通性として水に 対してる難溶性であるので，この性状を補足する方法， 手段として※テルアルコールや水で予め稀秎して添加す

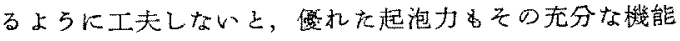
を発揮することができない感れがある。 